\title{
La proclamación de Carlos IV en Cádiz: Análisis estilistico e iconográfico
}

\section{M.ㄹ DOLORES BARROSO VAZQUEZ}

\section{RESUMEN}

En las grandes cortes europeas las fiestas que acompañan el curso de la vida del principe son vistas como rito colectivo, simbolizando para toda la comunidad los hitos cruciales de la vida pública y privada, proyectadas en la esfera del máximo poder. El Arte como cómplice de la monarquía, contribuye a fijar la continuidad de la institución a través del rico entramado de la arquitectura efímera. A través de uno de estos fastos, la proclamación regia, comprobamos la efectividad de esta práctica, utilizando como ejemplo la jura de Carlos IV en Cádiz.

\section{FIESTAS Y PODER}

Constituyen el pretexto gozoso y solemne para conmemorar, resaltar y fijar la continuidad de la institución monárquica a través de la fiesta (1). El arte se constituye así en el complice del poder político y espiritual. Arquitectos, escultores, pintores, músicos, poetas y un sin fin de artistas de todas las especialidades, aunan esfuerzos para transformar la faz cotidiana de la ciudad en un nuevo y maravilloso' teatro en el que todos serán actores y receptores del espectáculo. Calles y plazas se llenan de margníficas fachadas, fuentes, riscos y arcos triunfales de madera, transformados en suntosos edificios de bronce, mármoles y jaspes de los más variados colores gracias a los pinceles de los pintores. La técnica y la' fantasía artística creaban la ilusión de una ciudad nueva, más próspera y optimista, propiciando el marco idóneo en el que se explayaba el amplio repertorio iconográfico destinado a afianzar el orden establecido a través de las imágenes (2).

(1) M. FAGGIOLO y S. CARANDINI: L'Effimero Barroco. Structure della festa nella Roma del '600. Roma, Bulzoni Editore, 1977-1978.

(2) Baste recordar los frecuentes espectáculos desarrollados por los Medicis en la Florencia de los siglos XV y XVI, para comprobar la efectividad de esta práctica. El príncipe tutelaba al artista que crecía intelectual y técnicamente al lado del mecenas, metamorfoseando la ciudad para él, cuando las circunstancias así lo aconsejaban. Contemplamos por lo tanto la doble vertiente de la fièsta como instrumento de consolidación del poder, y como circunstancia que propiciaba la colaboración de los artistas y a veces el nacimiento de grandes obras de arte.

VV.AA.: El poder y el espacio: La escena del príncipe. Valencia, Diputaciones de Madrid, Barcelona, Sevilla y Valencia, 1990. 
Las obras efímeras, costeadas por mentores que estaban inmerosos en la cultura emblemática de tradición humanista, se constituyen en portadoras de conceptos a través de las imágenes. Reflejan una estrecha vinculación con los libros de empresas y emblemas, surgidos a partir de la Obra de Andrea Alciato, Emblematun liber publicada en Ausburgo en 1531. Traducida muy pronto en toda Europa, gozó de una gran difusión constituyendo la base de un amplísima literatura emblemática apoyada en la recuperación de las fuentes del mundo Antiguo, que contará con versiones más o menos inspiradas en la emblemática de Alciato en la mayoría de los países europeos afectos a la cultura humanista. A través de imágenes muy sencillas desde el punto de vista artístico, se ejemplarizaban virtudes y castigaban vicios, conformando uno de los apoyos decorativos y significativos más importantes del mensaje moral y político emitido a través del arte efímero por el poder.

La efectividad de esta práctica queda patentizada tanto por la pervivencia de este tipo de celebraciones de manera generalizada en nuestro país hasta bien entrado el siglo XIX, como por el empleo del lenguaje emblemático, ya obsoleto. No podemos ignorar el indudable resultado de la emblemática en el contexto de una población inculta, agena a las transformaciones de la Ilustración y anclada en comportamientos y prácticas propias del mundo efectista del Barroco.

En el contexto de la fiesta se crearán imágenes del poder de gran complejidad que poco a poco irán calando en el pueblo. Se enfatizan sus aciertos, la esperanza depositada en ellos y el deseo de buen gobierno, le llevan al autor del programa iconográfico a emplear emblemas y motes que resalten el celo del rey en el cumplimiento de sus deberes. Versado en artes y ciencias, heroico soldado, hombre piadoso y astuto gobernante, se forja la imagen del rey ideal, adornado con las máximas virtudes del hombre mortal, pero tocado con los símbolos paganos y católicos de la inmortalidad (3).

\section{PROCLAMACIONES REALES}

Dentro del emtramado ideológico que en el Antiguo Régimen sustentaba la institución monárquica, el mecanismo sucesorio jugaba el papel clave de legitimar a través de la permanencia en el trono de un mismo linaje, la perpetuación de la forma de gobierno. Se basaba en la existencia, subjetiva pero firmemente aceptada, de una línea biológica a través de la cual se transmitía la facultad carismática, casi taumatúrgica, de poder innata a la autoridad real. Esa cualidad heredada, como atributo de poder subrenatural, directamente delegado por Dios, es la que se convierte en fuente de transmisión legitima del poder para el sucesor.

El acto central de la proclamación en las ciudades españolas a lo largo de toda la Edad Moderna lo constituye la tremolación del estandarte real en nombre del nuevo monarca con el grito ritual de "Castilla, Castilla, por el rey nuestro señor" (4).

(3) J.A. PORCEL SALABLANCA: Gozo y corona de Granada en la proclamación de Carlos III. (Estudio preliminar de la edición facsímil de 1760 de Jesús Marina Barba). Granada, Universidad-Ayuntamiento, 1988.

(4) J.M. MORALES FOLGUERA: Cultura y arte efimero en Nueva España. Granada, Consejería de Cultura, Junta de Andalucia, 1991, pp. 60-61. 
El carácter público inherente a la ceremonia hace de ésta un momento especialmente propicio para la exhibición del dominio por parte de quienes controlan efectivamente la comunidad a través de las instituciones que protagonizan el acto. Corforme se va convirtiendo en puramente formal lo que éste tiene de aceptación soberana por parte de la ciudad de un nuevo rey, la significación politíca se traslada al ámbito local.

La excepcionalidad del momento, que truca la rutina cotidiana conformada por el trabajo y la religión, establece el clima propicio para la aceptación del mensaje por parte del pueblo envuelto en la parafernalia de los fastos. En el esplendor de la fiesta barroca la gente se deja arrastrar por la alegría colectiva, el individuo se siente coparticípe de un destino común ligado a su rey, que se muestra gracias al aparato iconográfico desplegado en la decoraciones efimeras, como la auténtica esperanza de progreso y seguridad. Se perpetuaba así el principio de transmisión sucesoria del sistema monarquico del Antiguo Régimen, a la vez que se establecía una válvula de escape a la difícil situación económica y social imperante en la España de los siglos XVII y XVIII (5).

Las proclamaciones regias constituyen uno de los ejemplos más gozosos de la fiesta barroca, perpetuado incluso en plena época contemporánea. La pervivencia de esta celebración se vió favorecida no sólo por su efectividad, sino también por el cumplimiento de una rígida etiqueta (6). Tras el fallecimiento del monarca, el aparato burocrático de la Corte desencadenaba el proceso de convocatoria de las reales exequias, efectuadas no sólo en la capital del reino, sino en todas las ciudades y villas como testimonio de homenaje al rey, a la muerte le seguía la vida, el trono no estaba vacío, el rey difunto abandonaba su estatus motal para subir al cielo a velar por sus súbditos junto a los seres celestes, y de forma automática, desmostrando la infalibilidad del sistema sucesorio, se procedia a manisfestar públicamente la proclamación y jura del nuevo rey.

No existió un marco jurídico para el cumplimiento de las exequias, la legislación se ocupó de regular ciertos aspectos del funeral y de frenar las ostentanciones de las exequias celebradas en honor de la aristocracia y los miembros de la Iglesia. Las leyes de los príncipes para que se reputasen por leyes perpetuas e inalterables, debían ser publicadas por las Cortes, pero en lo que se respecta a las celebraciones de esta clase no se conoce identificación alguna. Lo mismo ocurre con otro tipo de celebraciones, como las proclamaciones, actos que sólo necesitaban el requisito de la propia firma del soberano para convertirse en leyes. Las leyes que carecían de ser publicadas por las Cortes debían ser publicadas y obedecidas en calidad de Cartas o Cédulas Reales (7).

(5) Y.M. BERCE: Fete et Revolte. Des mentalités populaires du XVt'-XVII siècle. París, Hachete, 1976.

J.A. MARAVALL: La culturá del barroco. Madrid. Ariel, 1975.

(6) A. BONET CORREA: "La fiesta barroca como práctica del poder", Diwan, núms. 5-6, 1979, pp. 53-85.

(7) C. MARTINEZ-BARBEITO: "Las Reales Proclamaciones en La Coruña durante el siglo XVIII", Revista del Instituto José Cornide de Estudios Conuñeses, Año I, núm. 1, 1965, pp. 11-63.

Cfr. V. SOTO CABA: Catafalcos reales del Barroco Español. Un estudio de arquitectura efimera. Madrid, U.N.E.D., 1991, p. 73. 
A todos los ayuntamientos del reino llegaba la puntual noticia del óbito real, proclamándose de forma inmediata los lutos y el inicio del proceso de organización de los fastos reales. El corregidor designaba una comisión capitular que tenía bajo su responsabilidad la elección de los artistas encargados de las transformaciones urbanísticas, así como de los diseños más acertados, amén de un sin fin de tareas relacionadas con el decoro, el orden público, el cumplimiento del protocolo y la puntualidad de los actos. A las exequias le seguía la proclamación del nuevo rey, testimonio una vez más de la complejidad y dualidad de la cultura barroca que une la alegría con el llanto, lo sacro con lo profano y lo culto con lo popular en el marco aparentemente feliz y permisivo de la fiesta.

Ambas ceremonias reproducían un riguroso ritual, determinado por la propia corte, gestado a lo largo del siglo XVIII en el que quedaban establecidos los itinerarios, actos, manifestaciones religiosas y profanas, además de los procedimientos de licitación y subasta de los proyectos artísticos. A través del análisis de las obras efímeras erigidas en la de Cádiz en 1789 con motivo de la proclamación de Carlos IV, tendremos la oportunidad de comprobar la vigencia de la cultura barroca en pleno siglo de las Luces, en una ciudad abierta a las novedades de la Ilustración a través de la importante colonia europea establecidad en ella. Constataremos asi mismo la pluralidad del lenguaje estilístico empleado en los diferentes ingenios arquitectónicos, intentando establecer sus causas.

\section{PROCLAMACION DE CARLOS IV EN CADIZ}

Conocemos la dimensión y la estilística de las decoraciones efímeras ideadas en Cádiz con motivo de la proclamación de Carlos IV, gracias a la prolija descripción efectuada por Román Jaedo Cotesere y publicada en la imprenta de Antonio Murguía en 1790 (8). Responde a los cánones formales e ideológicos comunes a la amplia y reiterativa literatura generada por la fiesta (9). Sermones, descripciones y relaciones tanto de los actos como de los escenarios ideados por los artistas, fijan a través de la palabra impresa estas obras condenadas al desconocimiento. Constituyen por lo tanto una fuente de primera mano para la Historia del Arte, al suplir la escasez de dibujos, grabados y planos, recuperando la estructura, ornamentación y significado de unas obras que desaparecian con los últimos clamores de la fiesta.

En su Poema encomiástico Román Jaedo se describe como forastero imparcial, desgranando un discurso laudatorio que ensalza la vinculación de Cádiz con la Antigüedad, fuente de las virtudes de la ciudad, entre las que se encuentra la fidelidad a la monarquía. La obra sigue la estructura característica de este tipo de narraciones donde se entremezclan las opiniones del autor con las citas cultistas

(8) R. JAEDO COTESERE (1790): POEMA ENCOMIASTTCO O ELEGIO DE LA EXCMA. M.N.Y.L. Ciudad de Cádiz; DESCRIPCION DE SUS DECORACIONES, Y Adornos Püblicos y particulares ERIGIDOS PARA LA MAGESTUOSA PROCLAMACION de Nuestros Augustos Soberanos LOS SEÑORES D. Carlos IV. DE LUISA DE BORBON (Q.D.G.). ESCRIBIALO DON ROMAN JAEDO COTESERE. Con notas bistóricas y mithologicas para su mejor inteligencia. Cádiz, imprenta de D. Antonio Murguia.

(9) P. DAVILA FERNANDEZ: Los sermones y el arte. Valladolid, Universidad, 1980. 
en latín con continuas referencias a la mitología clásica y a la historia de la ciuldad. Se inicia con un prólogo titulado con sombrero de tres picos, $y$ bonores de Dedicatoria, en el que explica las cualidades de Cádiz y sus habitantes por su comportamiento en la Antigùedad, calificándola como un ejemplo para las naciones cultas. Continua con unas décimas tituladas el forastero imparcial en las que vuelve a insistir en el destacado papel desempeñado por la ciudad durante el dominio Romano, Pedro Angel Albisu: levantó en 1712 el Ayuntamiento, concluído por Torcuato Benjumeda. Altar mayor de la Iglesia del convento de San Agustín (10), primer retablo mayor neoclásico de la ciudad. Albisu dotó a sus retablos de una gran severidad y monumentalidad (1783). Retablo de Nuestra Señora de los Dolores, San Agustín, San Juan Bautista, San Lorenzo y San Juan Bautista (Corazón de Jesús y Sagrada Familia), Cristo de la Humildad y Paciencia y Ntra, Sra. del Tránsito (Ntra. Sra. del Mayor Dolor) (11).

Nacido en Zumárraga en 1753, inició su formación artística en la Academia de San Fernando de Madrid, donde ingresó en 1773. Con motivo de su participación en las obras del Arsenal de la Carraca se trasladó a Cádiz, donde trabajó desde 1780. Obtuvo la plaza de arquitecto de la ciudad en 1783 tras la muerte de Torcuato Cayón, cargo en el que permaneció hasta 1807. También ocupó el cargo de director de arquitectura de la Academia gaditana de Bellas: Artes hasta 1816, un año antes de'su' muerte.

\section{APENDICE DOCUMENTAL}

\section{Documento n. $\stackrel{1}{1}$}

Cádiz, 1789, Abril, 24.

Carta de obligación de Manuel de Arenas, pintor con los diputados del Consulado de Cargadores a Indias de Cádiz, ajustando la policromia de la estructura efimera costeada por esa institución con motivo de la celebración de la subida al trono de Carlos IV.

A.G.I., CONSULADO, legajo 91, exp. no 4 (1789).

Digo yo el avajo firmado haver combenido con los SSeñores Diputados de este Comercio para el aparato de la jura del Señor Don Carlos $4^{\circ}$ que se ha de poner delante de las puertas del Muelle en pintarlo todo en los terminos siguintes, supuesto haver visto, que esta ompuesto del dibujo que se esta practicando en el conbento de San Francisco formado por el Arquitecto Don Pedro Angel de Albisu. Todo lo exterior de las quatro Caras del edificio de madera deveran ir barnisadas a satisfación. Las Columnas pequeñas de una, y otra banda de blanco beteadas como marmol. Las ocho Columnas grandes de los ARcos iran Verdes jaspedas y beteadas y sus chapiteles y Pilastras bronceados en falzo, y lo mismo los perfiles de los Arcos. Toda la balaustrada blanca beteada como marmol. Los masisos y jarrones de ella como los demas de cornisas, Alquitraves, Frizo, y medias naranjas,

(10) ROMERO de Torres, E.: Catálogo monumental de España. Provincia de Cádiz. Madrid, Ministerio de Instrucción Pública y Bellas Artes, 1934, pp. 223 y 243.

(11) ROMERO de Torres, E. (1934): Op. cit., pág. 346. 
iran tambien veteadas segun el olor que mejor diga, y combenga: todo con barnis. Los jarrones de la Coronacion, y trofeos de los remates segun paresca y se me diga. El sentro del Salon que ha de representar el Edificio de un color a el temple, y veteado lo que corresponda a Jaspes. El suelo de la Galería de lozas y la graderia balanca de yesso. El techo de la misma Galería, a recuadros con trofeos pintados al temple. Por el exterior que mire a la Muralla entre las Pilastras, Varios Geroglíficos ya de Comercio, ya de Navios, u otras aluciones. Las ocho figuras que contiene el dibujo en el segundo cuerpo o Atico significaran = la abundancia $=$ la felicidad $=$ la $\mathrm{Paz}=\mathrm{la}$ Agricultura $=\mathrm{el}$ Comercio $=\mathrm{la}$ Esperanza $=1 \mathrm{a}$ justicia $=\mathrm{la}$ Astronomía + bien pintadas. Las diez figuras que contiene el intercolumnio del dibujo serán con sus nombres para que conoscan los siguientes Colon $=$ Cano $=$ Cortes $=$ albarado $=$ Sandoval $=$ Lugo $=$ Tapia $=$ Pizarro $=$ Magallanes $=$ Americo $=$ con los atributos que les Corresponda. Todo perfectamente acavado.

En el frente que hace el cuerpo Segundo o Atico donde señala el dibujo para inscripción se pintara de Jaspe blanco veteado deforma que reciva el rotulo que se me de para pintarlo en Letras grandes. Colocado que sea este Edificio de Madera por el Carpintero a Cuio cargo está la construccion de el es de mi cuenta destinar algu// nos oficiales para retocar alguna Junta o/ golpe que lleve alguna pieza antes ó despues de colocarla. Este trabajo en la forma explicada ha de ser de miobligación tenerlo concluido y acabado pra lo fines de Mayo Dias mas o menos en que esta Excelentisina Ciudad ponga y coloque sus Decoracioes para el mismo intento de la Jura. Cumpliendo como me obligo por esta Contrata a rodo los referido, dichos Señores Diputados del Comercio me habran de entregar mil ochocientos cinquenta pasos de a Ciento Veinte y ocho quartos cada uno, regulación, y precio en que hemos quedado de acuerdo, y para que conste y sirva de obligacion en forma mutuamente, se previene haver firmado dos de un tenor uno con que se quedan dichos Sseñores y otro para mi resguardo=

Cadiz, y Abril, 24 de 1789, Se previene que en todo me he de acordar para la obra con Don Pedro Angel de Albisu Sobre colores de Jaspes, y demas de la obra.

Manuel de Arena (rúbrica)///

\section{Documento n. 2}

Cádiz, 1789, Junio, 18.

Confirmación de la aceptación por parte de los diputados del Consulado de Cargadores a Indias de la propuesta del pintor Manuel de Arenas para el ajuste del precio de su intervención en las fiestas de la proclamación de Carlos IV.

A.G.I., CONSULADO, Legajo 91, exp. 4 (1789).

Somos contentos los Diputados que avajo subscrivimos, nombrados por el Comercio en Junta General de el, en la Contrata// anterior y sus condiciones y a pagar a dicho Señor Don Manuel de Arenas los mil ochocientos Cincuenta pesos de a 128 que corresponde a nuestra obligacion Verificado que sea, y Cumplido lo contenido en ella fecha ut supra He recivido del Señor Don Manue de Saavedra la Cantidad de que consta en la Contrata, con mas Cien reales (de) Vellon de el Dorado dela cuerdas delas Arañas.

Cadiz y Junio 18 de 1789.

Manuel de Arenas (rúbrica)///. 